\title{
Laser acupuncture to manage pain in child with sickle cell disease. Case report* $^{*}$
}

\author{
Acupuntura a laser no tratamento da dor em criança com anemia falciforme. Relato de caso \\ Carla Verônica Paixão Marques ${ }^{1}$ \\ ${ }^{*}$ Received from the Clinic of Pain and Acupuncture, Salvador, BA, Brazil. \\ - Study carried out as course conclusion paper to get the title of specialist in acupuncture by the Superior Institute of Health Sciences, \\ Salvador, BA, Brazil.
}

\section{ABSTRACT}

BACKGROUND AND OBJECTIVES: Sickle cell disease is the most frequent hereditary disease in Brazil, being considered a public health problem. It causes repetitive exposure to pain, which in childhood leads to permanent or long-term changes in the central nervous system and may lead to death. Management with drugs poses risks especially in terms of adverse effects. Natural, noninvasive methods, such as laser acupuncture, may be effective, cheap and useful to treat children affected by this disease, as well as they may decrease public expenses. This study aimed at showing the use of laser acupuncture for pain management in a child with sickle cell disease, thus decreasing drug ingestion.

CASE REPORT: Six years old child diagnosed with sickle cell disease having pain status evaluated by the Wong Baker scale for 2 weeks. In the first week the child was treated only with analgesics, if needed, and in the second week the child was submitted to daily laser acupuncture sessions, without receiving analgesics. CONCLUSION: Initial symptoms were significantly decreased with laser acupuncture and we decided to continue with the treated designed to further improve the balance obtained. Also, this study shows that laser acupuncture may considerably decrease the use of analgesics and, as a consequence, with potential to decrease their adverse effects.

Keywords: Acupuncture, Children, Laser, Sickle cell disease.

1. Superior Institute of Health Sciences, Salvador, BA, Brazil.

Submitted in August 19, 2013.

Accepted for publication in January 10, 2014.

Conflict of interests: none.

Correspondence to:

Carla Verônica Paixão Marques

Cond. Dom Gerônimo Bl 213/102 - Cabula 5

41150-320 Salvador, BA, Brasil.

E-mail: carlla.marques@hotmail.com

(C) Sociedade Brasileira para o Estudo da Dor

\section{RESUMO}

JUSTIFICATIVA E OBJETIVOS: A doença falciforme é a entidade hereditária mais frequente no Brasil, sendo considerada um problema de saúde pública. Provoca exposição repetitiva à dor, que na infância provoca alteraçóes permanentes ou de longa duraçấo no sistema nervoso central, assim como pode levar a óbito. $\mathrm{O}$ tratamento por meio de fármacos acarreta riscos quando são referidos os efeitos adversos. $\mathrm{O}$ uso de métodos naturais, não invasivos, como a acupuntura com laser pode ser eficaz, econômico e útil no tratamento das crianças acometidas por essa doença. A certeza da sua eficácia pode reduzir não só a ingesta farmacológica pelas crianças, como também reduzir gastos públicos. $\mathrm{O}$ objetivo deste estudo foi mostrar a utilizaçáo da acupuntura a laser no tratamento da dor em uma criança com anemia falciforme diminuindo a ingestão de fármacos.

RELATO DO CASO: Criança com 6 anos de idade, com diagnóstico da doença falciforme, tendo seu estado de dor avaliado através da escala Wong Baker por 2 semanas, sendo na primeira apenas tratada com analgésicos, se necessário, e na segunda semana sendo submetida diariamente à acupuntura laser, sem a ingestâo de analgésicos.

CONCLUSÂO: Observou-se redução significativa dos sintomas iniciais com o uso da acupuntura a laser, decidindo-se pela continuação do tratamento elaborado para melhorar ainda mais o equilíbrio obtido. Ainda, este estudo mostra que a acupuntura a laser pode reduzir consideravelmente o uso de fármaco analgésico, consequentemente com o potencial de reduzir os seus efeitos adversos.

Descritores: Acupuntura, Anemia falciforme, Crianças, Laser.

\section{INTRODUCTION}

The first cases of sickle cell disease (SCD) in children were described by Sydenstricker et al. in 1923, who have identified the association with the hemolytic phenomenon and have introduced the term "crisis" for acute pain episodes. It occurs early in life, as from few months of age, affecting small bones of hands and feet (hand-and-foot syndrome), which is typically the first painful manifestation of the disease ${ }^{1}$.

Sickle red cells do not adequately circulate in microcirculation, resulting both in capillary blood flow obstruction and in its own 
early destruction. This pathophysiological mechanism causes severe clinical manifestations, more frequently after three months of age $^{2}$.

Patients with mild pain should, according to the manual of SCD basic approaches published by the Ministry of $\mathrm{Health}^{3}$, be oriented to take analgesics, increase fluid ingestion and be revaluated the next day.

The World Health Organization (WHO) proposes the use of analgesics by a three-step ladder:

$1^{\text {st }}$ step - non-opioid analgesic/non-steroid anti-inflammatory drug (NSAIDs) \pm adjuvant;

$2^{\text {nd }}$ step - weak opioid \pm non-opioid analgesic / NSAIDS \pm adjuvant;

$3^{\text {rd }}$ step - strong opioid \pm non-opioid analgesic / NSAIDS \pm adjuvant.

The chart presents major types of analgesics used in the clinical practice, by pharmacological group.

Going beyond the maximum dose or the association with other drug from the same group will only increase adverse effects, without promoting satisfactory analgesia. Whenever adequate analgesia is not obtained, it is necessary to climb to the next analgesic ladder step ${ }^{4}$.

According to Bricks, it is critical to review prescription practices and health policies related to the use of drugs, considering that their unnecessary use may pose risks to the child and the community, in addition to wasting resources which would be better used to prevent diseases 5 .

One option is to treat with Traditional Chinese Medicine (TCM) also known as Chinese medicine (in Chinese: Zhongye xue, ou Zhongao xue) which, differently from Western Medicine which is only concerned with physical aspects and treats with industrialized drugs, sees the individual as a whole, restoring balance with natural methods. There are currently eight major TCM treatment methods:

1. Chinese phytotherapy (natural drugs);

2. Acupuncture;

3. Tuina or Tui Ná (Chinese massage and osteopathy);

4. Diet therapy (Chinese dietary therapy);

5. Auricular therapy (treatment through the ear);

6. Moxabustion;

7. Cup therapy;

8. Physical practices (integrated breathing and energy circulation exercises and meditation such as Chi Kung, Tai Chi Chuan and some martial arts) considered prophylactic methods to maintain health or intervention methods to recover it.

Acupuncture is a traditional Chinese medical therapy which uses fine metal needles to puncture the skin on specific body points to relieve pain and promote well-being. For TCM, pain is result of a condition of Qi or blood surplus or deficit ${ }^{6}$. WHO has approved in 1979, 43 indications for acupuncture and this number was increased to 64 in $1996^{7}$, being general pain control one of possibly treated diseases. By this technique, there is stimulation of certain skin points with needles, at a rate of 2 to $3 \mathrm{~Hz}$, activating nervous fibers which conduct stimuli, and causing a sequence of physiological reactions ${ }^{8}$.

Pediatric TCM treatment has special characteristics since chil- dren's channels and collaterals are still being formed, as well as their viscera and organs (Zang Fu), and blood and energy are insufficient, being then necessary to prevent the excessive use of acupuncture. For this reason, other therapeutic techniques are preferred, such as moxabustion, massage, traditional phytotherapy, auricular acupuncture and laser therapy ${ }^{9}$. In addition, aversion to needles has decreased the practice of acupuncture in Western countries children.

Laser, also known as noninvasive biostimulation, is an attractive alternative used for the last 25 years, because it consists of a fast treatment with low risk of infection and is considered ideal for patients with needle phobia. Low frequency laser used on acupuncture points provides a bright energy able to generate photobiological induction, producing biochemical and bioelectric effects on cells and providing anti-inflammatory, anti-algic and cell regenerator therapy ${ }^{10,11}$.

This study aimed at describing a case of laser acupuncture application in a child with sickle cell disease-induced pain.

\section{CASE REPORT}

Patient with 6 years of age, with sickle cell disease (SCD) diagnosed three years ago after mother having noticed fever, dark urine, upper limbs edema and difficulty to hold objects. Patient uses Tylenol when there are pain crises, these with mean frequency of once a week, and worsening with lower temperatures. Patient had never used alternative treatments.

In the first meeting, the child had no complaints and during evaluation of pain level by the Wong Baker scale, presented score zero. At energetic evaluation child had empty, fast, cordy, slippery pulse. Tongue was pale, without coating, with sublingual stagnation. Brittle appearance, diet poor in fruits and vegetables, little fluid ingestion, dark urine, daily loose stools, light sleep. The selection and use of these points occurred after a brief oral investigation of the patient and evaluation of pulse and tongue at every session. Within acupuncture theoretical perspective, it is possible to identify the quality of body organs Qi energy, namely, lungs, spleen-pancreas, Ming Men (Chinese medicine organ corresponding to one kidney), heart, liver and kidney by examining the pulse of the patient ${ }^{12}$.

Similar procedure may be performed by evaluating the tongue, which will present, in specific areas (corresponding to body organs), signs as edema, paleness, redness, cracks, coatings of different thicknesses and shades ${ }^{13}$. As from evaluation of tongue and pulse, the quality of energy of each organ may be classified as normal, excessive, stagnated, deficient or inexistent, being that each one of these characteristics will cause differentiated symptoms to patients, who are treated with stimulation, sedation or harmonization of specific acupuncture points ${ }^{11}$. The evaluated child had as post-evaluation diagnosis Yin deficiency, especially of liver and spleen-pancreas, and Xue deficiency with Qi energy flow impaired due to that.

Treatment aimed at maintaining Qi and Xue free flow, also favoring their production. Qi is produced by the energy of food $(\mathrm{Gu}$ $\mathrm{Qi}$ ), derived from food and beverage metabolism by the spleen (Pi) and stomach (Wei), combines with lungs air (Fei) and with 
blood (Xue) and Qi circulation through the body. Food energy (Gu Qi), derived from food and beverage, is transformed in Xue in the chest, by the action of the heart (Xin) and lungs (Fei). Jing's Yin aspect stored by kidneys (Shen) produces bone marrow which produces blood (Xue). Jing's Yang aspect, or original Qi - active source of transformations performed by heart (Xin) and lungs (Fei) in the upper burner and by spleen-stomach (Pi-Wei) in the middle burner.

Points based on this concept are ${ }^{14}$ :

R6 - (sixth kidney energy channel point): invigorates kidney's Yin, kidney deficit, nourishes Yin, especially when there is excess fire in heart, promotes sleep and body fluids;

C7 - (seventh heart energy channel point): invigorates heart, balances Yin and Yang, stabilizes the heart, clear the mind, calms mind and emotions, regulates spirit, invigorates blood, invigorates heart Yin, eliminates fire;

CS6 - (sixth heart/sexuality energy channel point): promotes Qi stagnation and calms its irregularities, removes blood and phlegm stagnation, calms the spirit, removes lungs Qi stagnation, invigorates heart; indicated for pain, shock and trauma;

E36 - (thirty-sixth stomach energy channel point): strengthens spleen and stomach to produce Qi and blood, which eliminate moisture; increases Qi, invigorates blood and Qi, stabilizes mind and emotions, regularizes defensive and nutritious Qi;

P9 - (ninth lung energy channel point): invigorates Qi of the lung, invigorates Yin of the lung, strengthens blood vessels and blood circulation;

IG4 - (fourth large intestine energy channel point): removes external wind, removes heat, relaxes muscle tension, promotes blood stagnation, calms liver Yang hyperactivity, calms the mind, invigorates Qi and blood;

IG11 - (eleventh large intestine energy channel point): expels exterior wind, removes heat, relaxes muscle tension and relieves pain, calms liver Yang hyperactivity, resolves moisture;

F3 - (third liver energy channel point): removes Qi and blood stagnation, calms liver Yang hyperactivity, eliminates liver wind and decreases spasms and pain; invigorates blood and calms the spirit;

F14 - (fourteenth liver energy channel point): moves liver Qi stagnation, eliminates liver moisture and heat; used for mental and emotional congestion;

VC4 - (fourth conception vessel energy channel point): strengthens kidney Jing, Qi, Yin and Yang, disperses Qi stagnation;

VC6 - (sixth conception vessel energy channel point): invigorates Qi deficiency and moves Qi stagnation;

VC12 - (décimo segundo ponto do canal de energia do vaso da concepção): harmoniza a preocupação e a insegurança, tonifica a deficiência do Qi e do Yang do baço, move a estagnação e regula a rebeliáo do Qi do estômago;

BP3 - (third spleen-pancreas energy channel point): moves spleen Qi stagnation invigorates deficiency and strengthens spleen, resolves mental depletion and blunting by moisture and phlegm;

BP6 - (sixth spleen-pancreas energy channel point): invigorates spleen, Qi and blood, eliminates moisture, invigorates Yin, calms the mind, regulates liver Qi;
BP9 - (ninth spleen-pancreas energy channel point): eliminates moisture.

The equipment used was the portable unit of microprocessed â $€$ " laser emission with a Nova Ciência's pen, used in the continuous mode, with frequency of $2.5 \mathrm{~Hz}$, the same of the needles, for 60 seconds on each selected point and repeated 12 minutes after, according to Gruber's protocol.

Pain was evaluated daily in the first meeting week through Wong Baker scale without laser intervention. In days 1, 2, 3 and 4 the child scored zero, with score 3 in day 5 with immediate administration of analgesic by the mother, maintaining score 5 in day 6 and score 1 in day 7 , still using paracetamol. Pulse and tongue evaluation was unchanged. In day 8 , still with score 1, low frequency laser acupuncture was applied. Alternative treatment was maintained throughout the week, every day. Child scored zero in days 9, 10, 11, 12, 13 and 14, with no need for analgesics. At Chinese evaluation we have observed a fuller pulse, with more Qi, and sublingual stagnation had disappeared. Weekly sessions were maintained for one month without new pain episodes.

\section{DISCUSSION}

Laser acupuncture is an analgesic technique commonly practiced in pediatric patients, with few studies on the subject, without clear recommendations and with no previous study published in the researched literature with regard to sickle cell disease $^{15}$.

The high number of patients with satisfactory response to low frequency laser positively evaluates the efficacy of such method as adjuvant for the treatment of trauma patients ${ }^{10}$.

A study proposed to treat asthma children had not a good response, credited by authors to the standardization of used points, without taking into consideration the individual evaluation of pulse and tongue?. In a systematic review on the use of laser acupuncture in asthmatic children, authors have concluded that the technique may even be effective, but there are few studies with small sample sizes and poorly consistent methodology ${ }^{16}$.

In a controlled study with 43 children with migraine and tension headache, authors have concluded that laser acupuncture was effective to decrease pain scores evaluated by the visual analog scale, as compared to placebo ${ }^{17}$. Such data open a range of possibilities for the use of this technique in painful children.

The favorable response of the child evaluated in this study suggests a real potential for treating pain of children with sickle cell disease with laser acupuncture, decreasing the use of analgesics. However, further studies are needed, including a control group, and even involving other variables, such as quality of life.

\section{CONCLUSION}

Laser acupuncture was effective in our case and may be an alternative method to treat pain in children with sickle cell disease, opening a discussion and a new dimension of complementary techniques, favoring the reduction of analgesic drugs ingestion. 


\section{REFERENCES}

1. Tostes MA, Braga JA, Len CA. Abordagem da crise dolorosa em crianças portadoras de doença falciforme. Rev Ciênc Méd. 2009;18(1):47-55.

2. Di Nuzzo DV, Fonseca SF. [Sickle cell disease and infection]. J Pediatr. 2004;80(5):34754. Portuguese.

3. Ministério da Saúde. Secretaria de Atençâo à Saúde. Departamento de Atenção Especializada. Manual de Condutas Básicas na Doença Falciforme. Série A. Normas e Manuais Técnicos. 2006

4. LoboI C, Marra VN, Silva RM. Crises dolorosas na doença falciforme. Rev Bras Hematol Hemoter. 2007;29(3):247-58.

5. Bricks LF. Judicious use of medication in children. J Pediatr. 2003;79(Suppl 1):S107-14

6. Taffarel MO, Salgado AE, Melo Filho EV, Teixeira LR, Fracalossi LD, Luz MR, et al. Efeitos da eletroacupuntura, aquapuntura e farmacopuntura em cadelas anestesiadas com isoflurano e submetidas à ovário-histerectomia. Arq Bras Med Vet Zootec. 2012;64(1):23-31.

7. Lu CC, Jan YM, Li TC, Hsieh CL. Electroacupuncture induces differential effects between Yin and Yang: a study using cutaneous blood flow and temperature recordings of the hand's dorsum and palm. Am J Chin Med. 2009;37(4):639-45.
8. Tostes MA, Braga JA, Len CA, Hilário MO. Avaliaçấo de dor em crianças e adolescentes portadores de doença falciforme. Rev Ciênc Méd. 2008;17(3/6):141-7.

9. Gruber W, Eber E, Malle-Scheid D, Pfleger A, Weinhandl E, Dorfer L, Zach MS Laser acupuncture in children and adolescents with exercise induced asthma. Thorax. 2002; 57(3):222-5.

10. Cabrera EB, Peron JM, Alfonso LE. Laseracupuntura com hélio-Neón en el tratamiento de pacientes traumatizados. Rev Cubana Med Milit. 2002;31(1):5-12.

11. Huang YY, Chen Aaron CH, Carrol JD, Hamblin MR. Biphasic dose response in low level light therapy. Dose Response. 2009;7(4):358-83.

12. Auteroche B, Navailh P. O diagnóstico na medicina chinesa. $1^{\text {a }}$ ed. Ed Andrei; 1992

13. Maciocia G. Os fundamentos da medicina chinesa. 2a ed. Săo Paulo: Roca; 2007.

14. Silva AL. O tratamento da ansiedade por intermédio da acupuntura: um estudo de caso. Psicol Cienc Prof. 2010;30(1):200-11.

15. Raith W, Litscher G, Sapetschnig I, Bauchinger S, Ziehenberger E, Muller W, et al. Thermographical measuring of the skin temperature using laser needle acupuncture in preterm neonates. Evid Based Complement Alternat Med. 2012;1:251-5.

16. Zhang J, Li X, Xu J, Ernst E. Laser acupuncture for the treatment of asthma in children: a systematic review of randomized controlled trials. J Asthma. 2012;49(7):773-7.

17. Gottschling S, Meyer S, Gribova I, Distler L, Berrang J, Gortner L, et al. Laser acupuncture in children with headache: a double-blind, randomized, bicenter, placebo-controlled trial. Pain. 2008;137(2):405-12. 